\title{
ATTITUDES AND PURCHASE INTENTION OF COUNTERFEIT APPAREL PRODUCTS IN TANZANIA: THE MODERATING ROLE OF LEVEL OF FORMAL EDUCATION
}

\author{
Sophia Mbura; Hawa Uiso, PhD and Saganga Kapaya, PhD \\ The Open University of Tanzania, Faculty of Business Management \\ http://doi.org/10.35409/IJBMER.2020.3211
}

\begin{abstract}
This study aimed to examine the moderating role of level of formal education on the relationship between attitude and purchase intention of counterfeit apparel products. The research was conducted in Dar es Salaam Tanzania using survey strategy involving a sample of 315 households. Structural Equation Modeling (SEM) using IBM SPSS Amos 23 was used to test the postulated hypotheses. The results before moderation revealed a positive and significant relationship between attitude and purchase intention. The multi-group moderation analysis confirmed that the level of formal education positively moderates the relationship between attitude and purchase intention of counterfeit apparel products. The relationship between the variables under study was found to be stronger in consumers with less formal education level as compared to those with high education level, implying that the level of formal education strengthened this relationship. The study recommended better marketing strategies and plans to be applied by original manufacturers and focus on educating different groups of consumers on the benefits and values of purchasing and using original products and how to differentiate them from counterfeits.
\end{abstract}

Keyword: Counterfeit Apparel Products, Attitude, Purchase Intention, Level of Formal Education.

\section{INTRODUCTION}

Counterfeiting is among the major economic global problems that are expanding very fast without showing any indicators of decline (Harun, Mahmud, Othman, Ali, \& Ismael, 2020). The Organization for Economic Cooperation and Development (OECD, 2016) insists that up to US\$ 641 billion or 2.5 per cent account for counterfeit products (CPs) in world trade. Counterfeit products are referred to as similar or identical copies of trademarked goods which are offered in the market to gain the benefits generated by specific branded products (Cademan, Henriksson, \& Nyqvist, 2012). Counterfeiting exists in almost all product categories including accessories, watches, pharmaceuticals, apparel products automotive parts, cosmetics, electronics such as television and radio sets, mobile phones, software, computers, media, and even currencies (Shunmugam, 2015). The presences of many counterfeit and pirated products pose harmful effect on the original manufacturers, as they destroy their original brands. Counterfeits also cause risk 


\section{International Journal of Business Management and Economic Review}

Vol. 3, No. 06; 2020

ISSN: 2581-4664

to the consumers' welfare as well as being a threat to the government because it leads to loss of government revenue

Counterfeits purchase intention has grown significantly worldwide and has become a serious subject of global concern (Bhatia, 2018; Chiu \& Leng, 2016; Harun et al., 2020; Jiang, Miao, Jalees \& Zaman, 2019; Priporas, Kamenidou, Kapoulas \& Papadopoulou, 2015). Previous scholars (Chui and Leng; 2016; Gani, Alam, Al-Islam, Chowdhury \& Faruq, 2019; Jiang et al.,2019 and Quoquab, Pahlevan, Mohammad \& Thurasany, 2017) identified the factors influencing consumers' purchase intention of CPs so as to show better understanding of the motive behind the purchase intention of CPs. Some of them used the Theory of Reasoned Action (TRA) and Theory of Planned Behaviour (TPB) to explain how consumers' purchase intention revealed inconsistent findings against TPB. Similarly, there are few studies whose findings indicate inconsistency with previous researches on the effect of demographic variable (age, income, gender and education) on consumers' purchase intention (Harun et al., 2020; Yoo and Lee, 2012). The demographic variables can either be used as predictor variables or as moderator variables in examining consumers' purchase intention so as to increase the explanatory power of the theory in predicting consumer purchase intention (Harun et al., 2020). Nonetheless, many studies on the factors influencing purchase intention towards counterfeit apparel products CPs have been conducted in developed countries such as in Asia, Europe and USA (Lwesya, 2017). In this case, a different context like Tanzania is considered a fertile ground because the number of factors and the extent of influence differ in terms of context, age, education and income. In addition, consumers' perception towards counterfeit products may be different (Bhatia, 2018). Hence the primary objective of this study is not only to examine the influence of attitude on consumers purchase intention of counterfeits apparel products (CAPs) in Tanzania, but also to assess the moderating effect of the level of formal education on the relationship between attitude and purchase intention of counterfeit apparel product; an area that has not been adequately investigated by researchers. In this study, level of formal education is referred to as the number of years that someone has spent in school (Talula, 2012) Therefore, understanding the influence of attitude towards counterfeit apparel products to consumers' purchase intention will add more insights to original products manufacturers and marketers to reduce purchase intention of CAPs.

\section{LITERATURE REVIEW}

\subsection{Theoretical Grounding and Hypothesis Development}

This study has banked on the Theory of Planned Behaviour and Ethical decision Making (EDM) theory as the theoretical framework. TPB originated from the Theory of Reasoned Action- TRA (Fishbein and Ajzen, 1975) with two variables (attitude and subjective norm) as main predictors of intention. However, in 1991 Icek Ajzen extended TRA into TPB by adding one variable that is perceived behavioural control and indicated to be a better predictor of intention and behaviour. Behavioural intention is the central factor of the TPB which is referred to as decision to act in a particular way and it is a strong predictor of the actual behaviour. The behavioural intention was first studied by Fishbein \& Ajzen (1975) through the Theory of Reasoned Action (TRA) then followed by Ajzen (1991) using the Theory of Planned Behaviour (TPB) in the studies of consumer behaviour. The behavioural intention is influenced by attitude, subjective norms and perceived behavioural control (Ajzen, 1991). Their studies revealed that positive or favourable 


\section{International Journal of Business Management and Economic Review}

Vol. 3, No. 06; 2020

ISSN: 2581-4664

attitude, subjective norm and perceived behavioural control determine consumer behavioural intention. Ajzen (1991) advanced that TPB can be expanded or modified to have a better understanding of the behaviour; he suggested that TPB can accommodate additional variables. In addition to that EDM theory was developed by Ferrell \& Gresham (1985). It is also used to predict behaviour for the studies related to counterfeits because it can provide an examination and prediction of ethical behaviour. EDM theory states that in dealing with ethical and or unethical issues, an individual decision depends on three variables which are individual factors, significant others and opportunities. Individual's factors including knowledge, values, beliefs (which in totality they are addressed to education), attitude and intention. Thus, this study focused mainly on attitude and (purchase intention) variables from TPB and education variable from EDM theory.

\subsection{Empirical Grounding and Hypothesis Formulation}

\section{Relationship between Attitude towards CAPs and Purchase Intention}

The attitude in the context of consumer behaviour refers to a person feeling or behavioural belief or affection towards something (Cademan et al., 2012). According to Phau, Sequeira \& Dix (2009), one of the important roles played by attitude is to influence consumers to purchase counterfeit products. The possibility of a consumer buying a counterfeit brand becomes high when there is a positive attitude towards counterfeit products. Likewise, the possibility of consumers purchasing counterfeit brands becomes low when the consumers have negative attitude towards counterfeit brands irrespective of the product category (Bhatia 2018).

Several studies have examined the influence of attitude towards counterfeit products on purchase intention and found a positive relationship (Bhatia, 2018; Carpenter \& Edward, 2013; Chui and Leng, 2016; De Matos, Ituassu \& Rossi, 2009; Koay, 2017; Moon \& Javaid, Kiran, Awan \& Farooq., 2018; Phau \& Teah, 2009, and Rizwan, Ali, Anjum, Naseer, Majeed, Ali, \& Anwar, 2014). However, a study conducted by Pham \& Nasir (2016) in the UK indicated that there was a negative relationship between consumers' positive attitude and purchase intention of the counterfeit products. Similarly, Eisend and Schuchert-Gular (2006) as cited by Riquelme, Abbas, \& Rios (2012) in Kuwait indicated that there was a negative relationship between consumers' favourable attitude toward CPs and counterfeits purchase intention. Ajzen (1991) revealed attitude as the main determinant of behavioural intention, hence the following hypothesis was developed

H1: There is a positive relationship between consumers' positive attitude towards counterfeit apparel products and purchase intention

\section{The Moderation Role of level of Education on the Relationship between Positive Attitude towards CAPs and Purchase Intention}

According to Kozar \& Marcketti (2008), education produces people with ethical and moral conscious by providing them with the guiding principles that are used in society. Therefore, their study indicated that educated people are more concerned with ethics, moral and sensitive with negative implications regarding the practice of counterfeiting, including manufacturing, selling and buying. Besides, their study had shown that educated people avoid themselves in counterfeiting activities because of fearing to commit crime Various researchers (De Matos et al., 2007; Carpenter \& Edwards 2011; Phau \& Teah 2009; 


\section{International Journal of Business Management and Economic Review}

Vol. 3, No. 06; 2020

ISSN: 2581-4664

Talula 2012) suggested that consumers with low level of education are more likely to purchase CPs. However, Moepswa (2016) in Botswana stated that people with a high level of education are less likely to enjoy buying CPs, meaning that they are less involved in purchasing CPs as compared to people with a low level of education towards the purchase of CPs. Level of education as a moderator variable is expected to change the purchase intention of consumers because it puts much weight on the attitude of CPs as predictor variable. Therefore, the level of formal education positively influences the consumers purchasing intention of CPs because consumers become too judgmental towards purchasing decision process. Additionally the purchasing decision process of counterfeit products involves ethical and moral judgments as well as risk assessment. Hence the following hypothesis was proposed

$\mathrm{H} 2$ : The level of formal education positively moderates relationship between consumers attitude and purchase intention of counterfeit apparel products

\section{Conceptual Framework}

This study proposed a conceptual framework (Figure 2.1) to back the argument on the influence of consumers' positive attitude towards counterfeit apparel products and purchase intention. The framework had been constructed based on the determinants of Theory of Planned Behaviour (TPB), and level of education from demographic variable. The framework comprised of three variables namely purchase intention as the dependent variable and attitude, being independent variables as well as level of education as a moderating variable

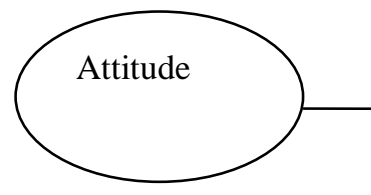

H1

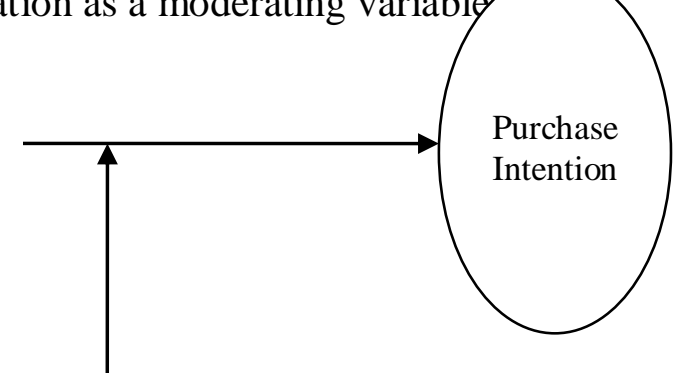

$\mathrm{H} 2$

Level of formal Education

Figure 2.1: Conceptual Framework

Source: Researcher construction based on the synthesis of the literature (2020)

\section{MATERIALS AND METHODS}

\subsection{Targeted Population and Area of the Study}

The study was conducted in Dar es Salaam region, involving consumers of apparel products as a target population. The justification for the choice of this region as a study area is based on the fact that 80 per cent of counterfeits products enter Tanzania through Dar es Salaam port, whereas 50 to 60 per cent of counterfeits are found in Dar es Salaam (CTI, 2017). Specifically, data were collected from the individuals in the households situated into different streets and districts of Dar es Salaam. Therefore, the chosen study area and population provided useful 


\section{International Journal of Business Management and Economic Review}

Vol. 3, No. 06; 2020

ISSN: 2581-4664

information as far as a study of the influence of attitude towards counterfeit apparel products and purchase intention is concerned. The sampling frame for this study was based on the Tanzania Population and Housing Census (TPHC) that was done in 2012. This consisted of a list of all streets found in all Dar es Salaam districts provided by the National Bureau of Statistics of Tanzania (NBS). According to NBS, there were 5 Districts in Dar es Salaam and 462 streets with 915,806 total numbers of households. These streets helped to identify the households, and through that, respondents for the current research were obtained.

\subsection{Sampling Procedure and Design}

The study employed probabilistic sampling procedure where it combined both multistage sampling and systematic sampling procedures. The selection of the probabilistic sampling procedures was appropriate for the quantitative study (Saunders, Lewis, \& Thornhill, 2012). Multistage sampling was used in dividing the population into various stages to obtain selected streets, selected households and listing of households. This study also employed a systematic sampling technique at the part of streets and household selection. Systematic sampling is the probability technique where the sample is drawn from the population with a random starting point and a fixed interval (Saunders et al., 2012). The random number was generated, a systematic interval of households was calculated, and from each interval, a street was selected until all required streets were identified

\subsection{Measurement Instrument and Data Collection}

The cross sectional study involved primary data collection from the field with the help of two research assistants. The data were collected through a self-administered questionnaire method. Questionnaires were structured with closed-ended questions which were administered to the chosen respondents. The use of questionnaire enabled the researcher to quantify the data based on the fact that the study adopted quantitative methodology (Saunders et al., 2012). The questionnaire was divided into two parts which were basic profile of respondents (part I) and 7 Point Likert-like scale statements (Part II) and these were regarded as the most suitable scale in the measurement of behavioural intention ( $\mathrm{Lu}, 2013$ ). Thus scale used for measuring demographic information was nominal scale where it was possible to assign the numbers of occurrences within the specific categories of the variables. The numbers were just used for the purposes of labels in order to identify and classify subjects (Hair, Babin, Anderson \& Black, 2010). The researcher collected data from 315 households' consumers of apparel products from different streets in Dar es- Salaam. Only 301 questionnaires were returned and screened for missing data. After thoroughly examining the returned questionnaires missing values were found in the three (3) questionnaires. The 3 questionnaires which had missing data in the section of respondents' basic profiles were deleted and remained with 298 usable questionnaires for data analysis. Hair et al. (2010) recommended that missing values of missing completely at random and they are less than $10 \%$ are subject for deletion since they can affect the sample size

\subsection{Measurement Variables of the Study}

\begin{tabular}{|l|l|l|l|l|l|}
\hline $\begin{array}{l}\text { Variabl } \\
\text { e }\end{array}$ & $\begin{array}{l}\text { No. } \\
\text { of } \\
\text { Item }\end{array}$ & $\begin{array}{l}\text { Cod } \\
\text { e }\end{array}$ & Measurement Items & Measurement & Sources \\
\hline
\end{tabular}


International Journal of Business Management and Economic Review

Vol. 3, No. 06; 2020

ISSN: 2581-4664

\begin{tabular}{|c|c|c|c|c|c|}
\hline & $\mathrm{S}$ & & & & \\
\hline $\begin{array}{l}\text { Attitud } \\
\text { e }\end{array}$ & 8 & AT & $\begin{array}{l}\text { AT1=Recommenda } \\
\text { tion } \\
\text { AT2=Benefit } \\
\text { AT3=Preference } \\
\text { AT4=Nothing } \\
\text { wrong } \\
\text { AT5=Better choice } \\
\text { AT6=Similar } \\
\text { quality } \\
\text { AT7=Similar } \\
\text { function } \\
\text { AT8=Reliable }\end{array}$ & $\begin{array}{l}\text { Seven point } \\
\text { scale } \\
\text { 1= strongly } \\
\text { disagree } \\
\text { 4= Neutral } \\
7=\text { Strongly } \\
\text { Agree }\end{array}$ & $\begin{array}{l}\text { Bhatia (2018), } \\
\text { Cheng et al., } \\
(2011), \text { Chiu \& } \\
\text { Leng (2016), de } \\
\text { Matos et } \\
\text { al.,(2007), \& Lu } \\
(2013)\end{array}$ \\
\hline $\begin{array}{l}\text { Purcha } \\
\text { se } \\
\text { Intenti } \\
\text { on }\end{array}$ & 4 & PI & $\begin{array}{l}\text { PI1=Think as a } \\
\text { choice } \\
\text { PI2=Consideration } \\
\text { PI3=Recommendati } \\
\text { on } \\
\begin{array}{l}\text { PI4=Plan } \\
\text { purchase }\end{array}\end{array}$ & $\begin{array}{l}\text { Seven point } \\
\text { scale } \\
\text { 1= strongly } \\
\text { disagree } \\
\text { 4= Neutral } \\
7 \text { = Strongly } \\
\text { Agree }\end{array}$ & $\begin{array}{l}\text { Bhatia (2018), de } \\
\text { Matos } \\
\text { al.,(2007), } \\
\text { Rizwan et al., } \\
\text { (2014), } \\
\text { Stumpf et al., } \\
(2011)\end{array}$ \\
\hline $\begin{array}{l}\text { Level } \\
\text { of the } \\
\text { formal } \\
\text { Educat } \\
\text { ion }\end{array}$ & 2 & LFE & $\begin{array}{l}\text { LFE1=1yr to } \\
\text { 13years } \\
\text { LFE2=14years and } \\
\text { above }\end{array}$ & $\begin{array}{l}\text { Categorical } \\
\text { scale } \\
\text { 1= low LFE } \\
\text { 2= high LFE }\end{array}$ & $\begin{array}{l}\text { Moepswa (2016), } \\
\text { \& Talula (2012) }\end{array}$ \\
\hline
\end{tabular}

Source: Researcher's computation from Literature, 2020

\subsection{Data analysis}

Before the actual data analysis, the collected data were virtually inspected to ensure that data were of a good quality. Data were entered in IBM Statistical Package for Social Scientists (SPSS) version 22 for analysis. The researcher checked for missing data, outliers and errors were obtained during data entry. IBM Amos software version 23 was utilized to run the CFA and SEM models. Descriptive analysis, inferential analysis and multi-group moderation analyses were performed. In this current study SEM was chosen because it is recommended by a comprehensive statistical approach that can handle multiple relationships among observed and latent variables (Hair et al., 2010).

\section{STUDY RESULTS}

\subsection{Respondents Profile}

Descriptive analysis was carried out to assess the respondents' basic profile information presented by frequencies and percentage. The results assisted the researcher in understanding the 


\section{International Journal of Business Management and Economic Review}

Vol. 3, No. 06; 2020

ISSN: 2581-4664

basic description of the respondents in the study and incorporated the results in the final data analysis

\subsubsection{Distribution of Respondents by Age, Gender and Marital Status}

Age of the respondents was a vital profile to be included in the sample because it provided the control, potential exposure and experience about counterfeits issues (Talula, 2012). From this analysis, the majority of the respondents fall in the age between 41 and 50 that reflect the age of people with enough life experience, economically active and make their own purchase decisions. With respect to gender, the results indicated a good balance $(57.7 \%$ were males and $47.3 \%$ were females). Moreover, the analysis of marital status indicated that majority of the respondents in this sample had fallen in married category indicating that they are well matured and can share different ideas and economic resources. Table 4.1 summarizes this information in detail.

\section{Table 4.1: Demographic Statistics for Age, Gender and Marital Status}

\begin{tabular}{|l|r|r|}
\hline & Frequency & Percent \\
\hline Age(Years Old) & \multicolumn{2}{|c|}{} \\
\hline $18-30$ & 25 & 8.4 \\
\hline $31-40$ & 98 & 32.9 \\
\hline $41-50$ & 123 & 41.3 \\
\hline Above 50 & 52 & 17.4 \\
\hline Gender & 157 & 57.7 \\
\hline Male & 141 & 47.3 \\
\hline Female & 31 & 10.4 \\
\hline Marital status & 239 & 80.2 \\
\hline Single & 13 & 4.4 \\
\hline Married & 9 & 3.0 \\
\hline Divorced & 6 & 2.0 \\
\hline Widow & \multicolumn{2}{|}{} \\
\hline Separated & \multicolumn{3}{|c|}{} \\
\hline
\end{tabular}

Source: Field Data, 2020

\subsubsection{Distribution of Respondents by number of years in schools}

In examining the sample about the number of years that respondents had spent in school, the results show that 162 respondents had spent between 0 and 13 years in school equals $58.1 \%$ composed of informal, primary and secondary education. 136 respondents were spent over 14 years in school equals to $41.9 \%$ which composed of diploma, bachelors, masters and PhD degree as shown in table 4.2

Table 4.2: Respondents Number of Years Spent in School 


\section{International Journal of Business Management and Economic Review}

Vol. 3, No. 06; 2020

ISSN: 2581-4664

\begin{tabular}{|l|l|r|r|}
\hline \hline Years & Frequency & Percent \\
\cline { 2 - 4 } & $0-13$ & 162 & 54.4 \\
\cline { 2 - 4 } & Above 14 & 136 & 45.6 \\
\hline Total & 298 & 100.0 \\
\hline
\end{tabular}

Source: Field Data, 2020

\subsection{Measurement Model Analysis}

The measurement models were tested by using Confirmatory Factor Analysis (CFA). Initial CFA was done in IBM Amos version 23 using Maximum Likelihood Estimation so as to examine the model fit. According to Hair et al. (2010), the researcher was able to assess the contribution of every scale item that showed the extent of the reliability of the scale in measurements based on the unobserved construct. Thus, all the constructs were put to CFA for assessing factor loading, validity, reliability of the constructs and multicolliniearity.The overall CFA results demonstrated that all the factor loadings associated with the measurement model were satisfactory implying that the research factors had good reliability. In addition, Yuan and Bentler (2000) stated that items with negative regression weight suggest distrustful measurement models. However, Hox and Bechger (2014) stressed on factors loading of below 0.5 being insignificant. In this view, the final results of the measurement model were satisfactory as portrayed in figure 4.1

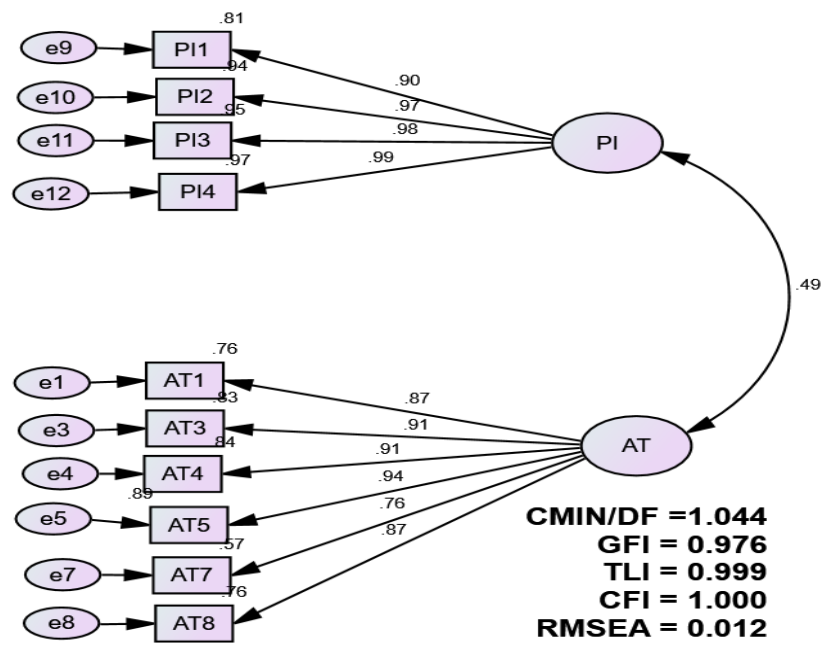

Figure 4.1: Measurement Model

Source: Field Data, 2020

\subsubsection{Factor Loadings}

All the factors have met the threshold value of 0.5 and above as recommended by Hair et al. (2010) which prove the presence of significant factor loadings Yong and Pearce (2013), implying that the research factors had good reliability. The results for model fit indicated good fitness of 


\section{International Journal of Business Management and Economic Review}

Vol. 3, No. 06; 2020

ISSN: 2581-4664

the model as referred to cutting off criteria for the model fit proposed by Awang (2011). Figure 4.1 demonstrates the factor loading for measured variables and model fit indices.

\subsubsection{Reliability}

The reliability of a set of items used to measure particular attributes of a factor was assessed by checking the internal consistency using the Cronbach's alpha value. Consequently, the reliability of latent variable was measured by Composite Reliability (CR) using CR values. The results from this study showed all the values of Cronbach's alpha were above 0.7 , as indicated in table 4.3, implied internal consistency was achieved. The CR value of greater than 0.5 as shown in Table 4.3 justifying that items were reliable and measured what they were supposed to measure; hence internal consistency reliability was achieved.

\subsubsection{Convergent Validity}

Average variance extracted (AVE) was used to test the convergent validity of the model. This study employed the formula provided by Awang (2011) to compute the AVE for every construct in the excel spreadsheet. Table 4.3 indicated that all AVE values were above the recommended value of 0.5 , which proved that convergent validity was adequately achieved.

Table 4.3: Reliability and Convergent Validity

\begin{tabular}{|l|l|l|l|}
\hline Construct & $\begin{array}{l}\text { Cronbach's } \\
\text { alpha value }\end{array}$ & $\begin{array}{l}\text { Composite } \\
\text { Reliability (CR) }\end{array}$ & $\begin{array}{l}\text { Average Variance } \\
\text { Extracted (AVE) }\end{array}$ \\
\hline Attitude (AT) & 0.957 & 0.952859 & 0.63385 \\
\hline $\begin{array}{l}\text { Purchase Intention } \\
\text { (PI) }\end{array}$ & 0.977 & 0.979501 & 0.92285 \\
\hline
\end{tabular}

Source: Field Data, 2020

\subsubsection{Discriminant Validity}

Discriminant validity was assessed by comparing between the square root of the Average Variance Extracted (AVE) and correlation of latent constructs as recommended by FornellLacker (1981). In this study, the AVE estimates were higher than the squared correlation estimates of the constructs as recommended by Awang (2011), Table 4.4 showed the diagonal pattern of all the correlation and square roots of the AVEs proved the discriminate validity was adequately achieved.

Table 4.4: Discriminant Validity

\begin{tabular}{|l|l|l|}
\hline Construct & Attitude (AT) & $\begin{array}{l}\text { Purchase Intention } \\
\text { (PI) }\end{array}$ \\
\hline Attitude (AT) & $\mathbf{0 . 7 9 6 1 4 7}$ & $\mathbf{0 . 9 7 9 5 0 1}$ \\
\hline $\begin{array}{l}\text { Purchase Intention } \\
\text { (PI) }\end{array}$ & -.555 & \\
\hline
\end{tabular}

Source: Field Data, 2020

\subsubsection{Multicollinearity Test Results}

The Variance Inflated Factor (VIF) was employed to examine the presence of multicollinearity. Hair et al. (2010) suggested that the threshold for value for VIF should be less than 5. The results from this study indicated that all VIF for independent variables were less than 5 as shown in 


\section{International Journal of Business Management and Economic Review}

Vol. 3, No. 06; 2020

ISSN: 2581-4664

table 4.5, reflecting the absence of multicollinearity cases. However, VIF values express the lack of Common Method Bias (CMB) where they were less than 3. According to Kock (2015) purported that the VIF values of $\leq 3.3$ imply that the model has absence of CMB

Table 4.5: Variance Inflated Factor (VIF) to Check Multicolliniearity

\begin{tabular}{|l|l|}
\hline Construct & VIF \\
\hline AT & 1.229 \\
\hline \multicolumn{2}{|l|}{ Dependent Variable: PI } \\
\hline
\end{tabular}

Source: Field Data, 2020

\subsection{Hypothesis Testing Results}

The postulated hypotheses for this study were tested based on Structural Equation Modelling (SEM) method. Various coefficients and scores attained from the structural model analysis were used to determine the relationship between the variables in proposed hypotheses. The structural model results indicated a positive and significant effect of attitudes towards CAPs on consumers'purchase intention $(\gamma=0.49, \mathrm{p}<0.05)$ which supported the proposed hypothesis. Hence, $\mathrm{H} 1$ was accepted as illustrated in figure 4.2

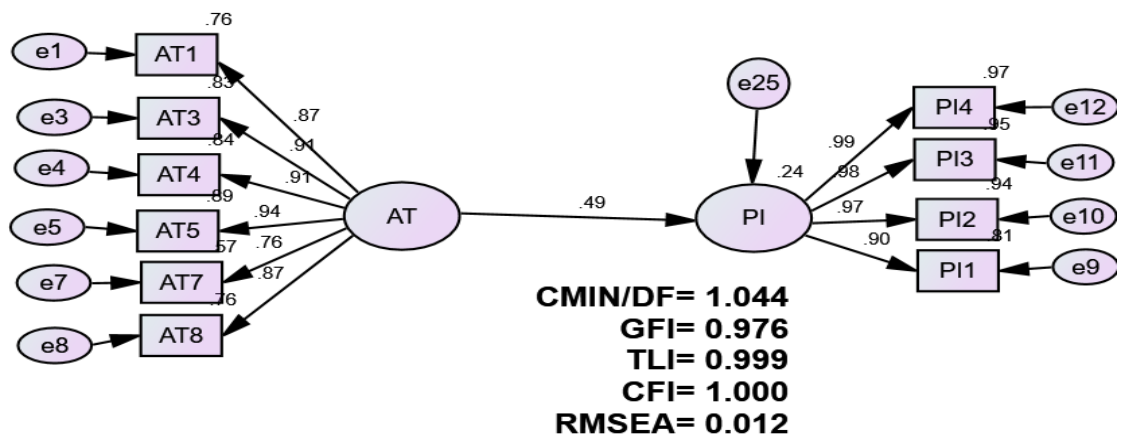

Figure 4.1: Structural Model

Source: Field Data, 2020

\subsection{Multi-group moderation Results}

To assess the moderating effects of level of education, the sample was divided into less and high education level groups. The multi-group analysis revealed results of chi-square difference test using IBM AMOS 23 which indicated that the two models were different in terms of the less education level and high education level groups $(\mathrm{p}<0.01)$ as illustrated in Table 4.5 
International Journal of Business Management and Economic Review

Vol. 3, No. 06; 2020

ISSN: 2581-4664

Table 4.5: The Effect of Positive Attitude towards Counterfeit Apparel Products on
Purchase Intention for Less and High Level of Formal Education

\begin{tabular}{|l|c|c|l|}
\hline & Standardized Estimate & $\mathbf{P}$ & Result \\
\hline $\begin{array}{l}\text { Less Level of } \\
\text { Formal Education }\end{array}$ & .620 & $* * *$ & Significant at $\mathrm{p}=0.000$ \\
\hline $\begin{array}{l}\text { High Level of } \\
\text { Formal Education }\end{array}$ & .013 & .164 & Insignificant at $\mathrm{p} \leq 0.05$ \\
\hline
\end{tabular}

Source: Field Data, 2020

The moderating effect of level of education was more articulated in less level of education group $(\gamma=0.62, \mathrm{p}<0.05)$ where the relationship between AT and PI was significant compared to high level of education group $(\gamma=0.13, p=0.164)$ where the result was insignificant. Therefore, the results indicates that consumers with less education level hold high attitude towards counterfeit apparel products which positively influenced purchase intention of CAPs

\section{DISCUSSION OF THE RESEARCH FINDINGS}

The study focused on determining the effect of attitude towards counterfeit apparel products in Tanzania using level of education as a moderating variable. The findings confirmed again that attitude towards CAPs has a positive and significant relationship with purchase intention of CAPs $(\gamma=0.49 ; p<0.05$ indicated in figure 4.1). This implied that the more the positive attitude toward CAPs the higher the purchase intention of CAPs. The findings of this study are consistent with most previous studies by Bhatia (2018), Chui et al. (2014), Chiu \& Leng, 2016), De Matos et al. (2009), Harun et al. (2020), Kim and Karpova (2010), Koay (2017), Moon et al., 2019; Phau \& Teah (2009) and Rizwan et al. (2014) who revealed a positive relation between attitude towards CPs and purchase intention The findings were also consistent with TPB and extend the previous findings that it was a suitable theory in predicting consumers purchase intention of CPs (Bhatia, 2018; Chui et al, 2014; Chui \& Leng, 2016; Kim \& Kaporva, 2010: Lu, 2013, Penz and Stottinger, 2005). However, the results are contrary to Pham \& Nasir (2016) who revealed a negative relationship between consumers' positive attitude and purchase intention of counterfeit products. The reason is that the study was conducted in the UK which reflected a different social-economic development between the countries whereas as UK was well developed compared to Tanzania, so attitude towards CPs was not considered as important factor in purchasing decision process in the context of UK.

The findings also showed that the level of education positively moderated the relationship between attitude towards CAPs and purchase intention of CAPs. The findings revealed that there was a stronger relationship between attitude towards CAPs and purchase intention in consumers with less level of formal education than consumers with high level of education. The results also provided a clear picture associated with less level of formal education consumers that their favourable attitude towards CAPs depended on affordability, accessibility and functionality of the product, particularly in the developing country context (Moepswa, 2016). Furthermore, the perception of issues related to brand quality and branding awareness was primarily attached to a certain consumers group of education level, whereas quality and brand are sub-factors of 


\section{International Journal of Business Management and Economic Review}

Vol. 3, No. 06; 2020

ISSN: 2581-4664

experience and knowledge; hence people should not wonder that high level of educated consumers were more prepared to judge quality on the context of counterfeits leading to less positive attitude ( $\mathrm{Lu}, 2013)$.

\section{CONCLUSION AND RECOMMENDATIONS}

The results found that there is a positive and significant relationship between positive attitude towards CAPs and purchase intention. Therefore, the study concluded that more positive attitude towards CAPs positively influences consumers' purchase intention. The findings of this study also confirmed that the level of formal education moderated the link between positive attitude towards CAPs and purchase intention of CAPs. In this view, the study has drawn up the conclusion that attitudes towards CAPs play a more significant effect on consumers with less level of formal education as compared with the high level of formal education consumers. Therefore, consumers who hold a positive attitude towards CAPs in less level of formal education group influenced high purchase intention. This study recommended that original apparel products manufacturers and marketers should find ways and strategies of changing consumers' positive attitude towards CAPs. It also recommended that marketers and apparel brand owners should design education campaigns that are specific to different groups of consumers (less and high level of education)

\section{Areas for Future Research}

The study was conducted in Dar es Salaam region only. Hence the researcher suggests that further research should be done in more than one region so as to broaden the insights of consumer purchase intention based on geographical location. This study also based on cross-sectional design hence, future research might opt for longitudinal studies to identify if the study yields different findings

\section{REFERENCES}

Ajzen, I. (1991). The theory of planned behaviour. Organizational behaviour and human decision processes, 50(2), 179-211.

Awang, Z. (2011). A Handbook on SEM: Structural Equation Modelling $2^{\text {nd }}$ ed. Kelantan: Universiti Teknologi MARA

Bhatia, V. (2018). Examining consumers' attitude towards the purchase of counterfeit fashion products. Journal of Indian Business Research, (2), 193-207.

Cademan, A. Henriksson, R. and Nyqvist, V. (2012). The affect of counterfeit products on luxury brands: An empirical investigation from the Consumer Perspective. A thesis for the award of Bachelor degree at Linnaeus University School of Business and Economics, Sweden.

Carpenter, J. M. and Edwards, E. K. (2013). US consumers' attitude toward counterfeit fashion product. Journal of Textile and Apparel Technology and Management, 8(1), 1-16.

Chiu, W. and Leng, H. K. (2016) "Consumers' intention to purchase counterfeit sporting Singapore and Taiwan. Asia Pacific Journal of Marketing and Logistics, 28(1), 23-36

CTI (2017). The State of Counterfeit Goods in Tanzania. A Report prepared by the

De Matos, C. A., Ituassu, C.T. and Rossi, C. A. V. (2007). Consumer attitudes toward counterfeits: a review and extension. Journal of Consumer Marketing, 24(1), 36-47.

Eisend, M. and Schuchert-Guler, P. (2006). Explaining counterfeit purchases: A review and 


\section{International Journal of Business Management and Economic Review}

Vol. 3, No. 06; 2020

ISSN: 2581-4664

preview. Academy of Marketing Science Review, 12, 1-25.

Ferrell, O. C. and Gresham, L. G. (1985). A contingency framework for understanding ethical decision making in marketing. Journal of Marketing, 49(3), 87-96.

Fishbein, M. and Ajzen, I. (1975). Belief, attitude, intention, and behaviour: An Introduction to Theory of Research, Reading. MA: Addison, Wesley

Fornell, C.and Larcker, D.F. (1981). Evaluating structural equation models with unobservavariables and measurement error. Journal of Marketing Research. 18 (1), 39-50.

Gani, O. M, Alam, I. M, Al-Islam, M, Chowdhury A. S. and Faruq, M. O. (2019).

Factors affecting consumers' purchase intention for counterfeit luxury goods in Bangladesh. Innovative Marketing, 15 (4)

Hair, J. F, Babin, J. B., Anderson, R.E. and Black, C.W. (2010). Multivariate data analysis. ( $7^{\text {th }}$ edition). Upper Saddle River: Pearson Prentice Hall.

Harun, A., Mahmud, M., Othman, B., Ali, R. and Ismael, D. (2020). Understanding experienced consumers towards repeat purchase of counterfeit products: The mediating effect of attitude. Management Science Letters , 10(1), 13-28

Hox, J .J. \& Bechger, T. M. (2014). An Introduction to Structural Equation Modeling. Family Science Review, 11(2), 354-373.

Jiang, Y., Miao, M., Jalees, T. and Zaman, S.I. (2019), "Analysis of the moral mechanism to purchase counterfeit luxury goods: evidence from China", Asia Pacific Journal of Marketing and Logistics, 31 (3), 647-669

Kim, H. and Karpova, E. (2010). Consumer attitudes toward fashion counterfeits: application of the theory of planned behaviour. Clothing and Textile Research Journal, 28(2), 79-94.

Koay, Y. K. (2018). Understanding consumers' purchase intention towards counterfeit luxury goods: An integrated model of neutralisation techniques and perceived risk theory. Asia Pacific Journal of Marketing and Logistics, 30 (2), 495-516

Kock, N. (2015). Common method bias in PLS-SEM: A full collinearity assessment approach. International Journal of e-collaboration, 11 (4), 1-10.

Kozar, M. J. and Marcketti, B. S. (2008). Counterfeiting education influencing ethical decision making. Journal of family and consumer science, 100(4), 49-50

$\mathrm{Lu}, \mathrm{M}$. (2013). An investigation of consumers' motives to purchase counterfeit luxury branded products, Masters of Research Thesis, University of Wollongong, Australia.

Lwesya, F. (2017). Factors influencing the marketability of counterfeit and pirated products in Dar-Es-Salaam Region, Tanzania: A factorial analysis. Saudi J. Humanities Soc. Sci, 2(1), 95105.

Moepswa, M. T. (2016). The threat of counterfeit devices: complicity vs vigilance. The journal of business research and management, 7 (1).

Moon, M. A., Javaid, B., Kiran, M., Awan, M. H. and Farooq, A. (2018). Consumer perception of counterfeit clothing and apparel products attributes. Marketing Intelligence and planning. 36(7), $794-808$.

My Pham, T. \& Nasir, M. A. (2016). Conspicuous Consumption, Luxury Products and Counterfeit Market in the UK. The European Journal of Applied Economic, 13 (1), 72-83

NBS (2019).National Statistical Survey, Dar es Salaam, Tanzania

OECD (2016). The magnitude of counterfeiting and piracy of tangible products - an update.

Available at http://www.oecd.org/dataoecd/57/27/44088872 


\section{International Journal of Business Management and Economic Review}

Vol. 3, No. 06; 2020

ISSN: 2581-4664

Penz, E. and Stottinger, B. (2005). Forget the real thing - take the copy: A explanatory model for the volitional purchase of counterfeit products. Advances in Consumer Research, (32), 568-575

Phau, I. and Teah, M. (2009). The devil wears (counterfeit) Prada: a study of antecedents and outcomes of attitudes towards counterfeits of luxury brands. Journal of Consumer Marketing, $26(1), 15-27$.

Priporas, C., Kamenidou, I., Kapoulas, A. \& Papadopoulou, F . (2015). Counterfeit purchase typologies during an economic crisis. European Business Review, 27 (1), 2-16.

Quoquab, F., Pahlevan, S., Mohammad, J. \& Thurasany, R. (2017). Factors affecting consumers' intention to purchase counterfeit products: an empirical study in the Malaysian market. Asia Pacific Journal of Marketing and Logistics, 29(4), 837-853.

Riquelme, E. H., Abbas, S. M. E. and Rios, E. R. (2012). Intention to purchase fake products in the Islamic country. Education business and society: contemporary Middle Eastern issues, 5(1), 6-22.

Rizwan, M., Ali, A., Anjum, H., Naseer, D., Majeed, Z., Ali, A. M. and Anwar, A. (2014). Consumers purchase intention towards counterfeit mobile phones. Journal of Public Administration and Governance, 4(3), 2161-7104.

Saunders, M., Lewis, P. and Thornhill, A. (2012). Research methods for business students $\left(6^{\text {th }}\right.$ ed.). England: Harlow Pearson Educational Limited.

Shunmugam, N. (2015). Consumer intention of purchasing authentic brands versus Counterfeits in South Africa. University of Pretoria, South Africa.

Tulula, M. J. (2012). The Demand for counterfeit goods in Kenya: A case study of mobile phones. The University of Nairobi Kenya. The research project for award of masters degree of Arts and Economics at the University of Nairobi, Nairobi, Kenya.

Yong, A. G. and Pearce, S. (2013). A beginner's guide to factor analysis: Focusing onexploratory factor analysis. Tutorials in Quantitative Methods for Psychology,9(2),79-94

Yoo, B., and Lee, S. H. (2012). Asymmetrical effects of past experiences with genuine fashion luxurybrands and their counterfeits on purchase intention of each. Journal of Business

Research, 65(10), 507-1515

Yuan, K. H. \& Bentler, P. M. (2000). Three Likelihood-Based Methods for Mean and Covariance

Structure Analysis With Nonnormal Missing Data. Sociological Methodology, 30, 165-200. 